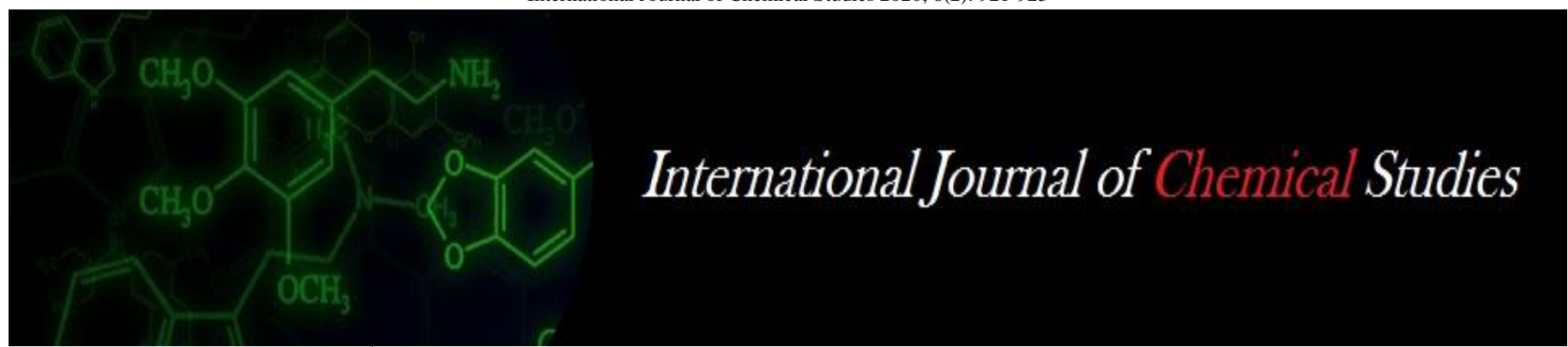

P-ISSN: 2349-8528

E-ISSN: 2321-4902

www.chemijournal.com

IJCS 2020; 8(2): 921-923

(C) 2020 IJCS

Received: 22-01-2020

Accepted: 24-02-2020

Shalini Dwivedi

Department of Soil Science,

College of Agriculture,

G.B.P.U.A.T Pantnagar,

Uttarakhand, India

Ajaya Srivastava

Department of Soil Science,

College of Agriculture,

G.B.P.U.A.T Pantnagar,

Uttarakhand, India

\section{SP Gangwar}

Department of Soil Science, College of Agriculture,

G.B.P.U.A.T Pantnagar,

Uttarakhand, India

\section{Veer Singh Bora}

Department of Soil Science, College of Agriculture,

G.B.P.U.A.T Pantnagar,

Uttarakhand, India

\section{Pradip Dey}

Department of Soil Science,

College of Agriculture,

G.B.P.U.A.T Pantnagar,

Uttarakhand, India
Corresponding Author: Pradip Dey

Department of Soil Science,

College of Agriculture,

G.B.P.U.A.T Pantnagar,

Uttarakhand, India

\section{Impact of organic and inorganic nutrient resources on the soil properties on soybean crop grown on Mollisol of Tarai region of Uttarakhand}

\author{
Shalini Dwivedi, Ajaya Srivastava, SP Gangwar, Veer Singh Bora and \\ Pradip Dey
}

DOI: https://doi.org/10.22271/chemi.2020.v8.i2n.8886

\begin{abstract}
A field experiment was conducted under All India Co-ordinate Research Project on "Long term Fertilizer Experiment" during Kharif season 2014-15 with soybean-wheat cropping system at the $\mathrm{D}_{3}$ block of the Norman E. Borlaug Crop Research Centre, G.B. Pant University of Agriculture and Technology, Pantnagar. The present investigation was assess the chemical properties of a Mollisol. There were ten treatments with the three replications in Randomized Blok Design (RBD) in soybean crop. The treatments were T1 (un-manured control), T2 (NPK 100\% RDF), T3 (NPK 50\% RDF), T4 (NPK 100\% $\left.\mathrm{RDF}+5 \mathrm{~kg} \mathrm{ZnSO} 4 \mathrm{ha}^{-1}\right)$, T5 STCR Targeted yield 1 (inorganic mode), T6 STCR Targeted yield 2 (inorganic mode), T7 (NPK 100\% RDF + 5 ton FYM ha ${ }^{-1}$ ), T8 (NPK 50\% RDF + 5 ton FYM ha ${ }^{-1}$ ), T9 STCR Targeted yield 1 (organic mode +5 ton FYM ha ${ }^{-1}$ ), T10 STCR Targeted yield 2 (organic mode +5 ton FYM ha-1). The result obtained from the present investigation clearly indicated that chemical properties changes in $\mathrm{pH}$ and $\mathrm{EC}$ in surface soil under different treatments were statistically nonsignificant. However, the treatments of combined application of chemical fertilizers with and without FYM have significant effect on organic carbon content, available nitrogen, phosphorus and potassium content in surface soil of soybean under soybean-wheat cropping system.
\end{abstract}

Keywords: Soil properties, $\mathrm{pH}, \mathrm{EC}$, organic carbon content, available nitrogen, phosphorus, potassium and FYM, soybean and wheat cropping system

\section{Introduction}

The application of chemical fertilizers alone in soil, which supply the nutrients in soil have negative impact on the soil health and causes the deterioration of soil and reduced the crop yield in India ${ }^{[3]}$. But now a day, to obtain maximum profit and maximum yield the farmers are using more chemical fertilizers in soil every year, due to excessive use of the chemical fertilizers directly affects the fertility status and reduces the microbial population in soil and also decline the soil productivity, Therefore agriculture soil scientist has come to namely integrated nutrient management practices (INM). In the INM practices combined use of organic and inorganic fertilizers in the various quantities which not only maintain higher productivity but also provide sustainability and also increases the nutrient use efficiency by crop $^{[2]}$.

Therefore the present study was undertaken to investigate the "Impact of Organic and Inorganic Nutrient resources on the soil properties of soybean crop grown on Mollisol of Tarai region of Uttarakhand.

\section{Materials and Methods}

Field experiments were conducted during Kharif season of 2014-15 at D3 Block of the Norman E. Borlaug Crop Research Centre, G.B.Pant University of Agriculture and Technology, Pantnagar, situated at $29^{\circ} \mathrm{N}$ latitude, $79^{\circ} 30^{\prime} \mathrm{E}$ longitudes and at altitude of 243.83 meter above mean sea level. The experimental soil is silty clay loam Mollisol. The experimental soil is silty clay loam soil, belonging to the Beni silty clay loam soil series of fine, mixed loamy, hyperthermic, family of great group Hapludoll, sub group- Aquic Hapludoll, sub order - Udoll, and known as Mollisol. Ten treatments were three replications in Simple randomized block design in soybean crop. 
The treatments were T1 (un-manured control), T2 (NPK $100 \%$ RDF), T3 (NPK 50\% RDF), T4 (NPK 100\% RDF + 5 $\mathrm{kg} \mathrm{ZnSO}_{4} \mathrm{ha}^{-1}$ ), T5 STCR Targeted yield 1 (inorganic mode), T6 STCR Targeted yield 2 (inorganic mode), T7 (NPK 100\% $\mathrm{RDF}+5$ ton FYM ha-1), T8 (NPK 50\% RDF + 5 ton FYM ha $^{-1}$ ), T9 STCR Targeted yield 1 (organic mode +5 ton FYM $\mathrm{ha}^{-1}$ ), T10 STCR Targeted yield 2 (organic mode +5 ton FYM ha ${ }^{-1}$ ). Where 100\% NPK stands for 20: 80: $40 \mathrm{~kg} \mathrm{ha}^{-1}$ recommended dose of fertilizer for soybean crop. For the present study one set of each soil samples were collected with the help of khurpi from the selected sites from each plot as per treatments for surface soil $0-15 \mathrm{~cm}$ depth soil after harvest of soybean crop grown during 2014-15. Soil $\mathrm{pH}$ was determined in a 1: 2 soil: water suspension by glass electrode $\mathrm{pH}$ meter (Jackson, 1958). The soil suspension used for $\mathrm{pH}$ determination was allowed to settle down and conductivity of supernatant liquid was determined by using conductivity meter Black and Bover (1954). The EC results are expressed in $\mathrm{dSm}^{-1}$ at $25^{0} \mathrm{c}$ and organic carbon content (\%) in soil was determined by Walkley and Black method (1934). Available nitrogen in soil was determined by the Alkaline potassium permagnate method (Subbiah and Asija, 1956). Available phosphorus in soil was determined by the Olsen 'extraction method (Olsen et al., 1954). Available potassium in soil was determined by Neutral normal ammonium acetate method (Jackson, 1973).

\section{Result and discussion \\ Soil pH}

The perusal of the data on soil reaction of the experimental soil indicated that continuous use of the chemical fertilizers alone and combined with the organic manure (FYM) has resulted a slight change in soil $\mathrm{pH}$. The data on the soil $\mathrm{pH}$ of the surface soil as influenced by application of chemical fertilizer alone or combined with the organic manure (FYM) after harvest of soybean crop is presented in Table 1. Data clearly indicated that $\mathrm{pH}$ of the surface soil was not affected significantly by combined application of chemical fertilizer along with the organic manure (FYM) or chemical fertilizer alone. No significant change in soil $\mathrm{pH}$ under different treatments was might be due to buffering capacity of Mollisol. ${ }^{[8]}$ reported that the application of chemical fertilizers over a longer duration increased soil $\mathrm{pH}$. However, combined use of chemical fertilizers with the organic manure (FYM) reduced the soil $\mathrm{pH}$ in soybean crop because it may be due to the buffering capacity of soil to resist the soil $\mathrm{pH}$ which does not change in soil $\mathrm{pH}$, similar, findings were reported by ${ }^{[7,1]}$.

\section{Electrical Conductivity}

The Data on (Table 1) clearly showed that electrical conductivity of the surface soil $(0-15 \mathrm{~cm})$ after harvest of soybean crop was not affected significantly by the treatments of application of integrated nutrients. Electrical conductivity of surface soil was varied from 0.12 to $0.21 \mathrm{dSm}^{-1}$ in soybean crop respectively. Further it was observed that electrical conductivity of the surface soil was lowest obtained in control treatment and highest in integrated nutrient treatment. Similar findings were reported by [7] observed that continuous application of chemical fertilizers alone or along with organic manure increased electrical conductivity of the surface soil because accumulation of the high amount of the salt in surface soil which increased the electrical conductivity of the surface soil.

\section{Soil organic carbon}

The responses of combined application of organic and inorganic nutrient resources on the soybean crops are illustrated in Table 1. The data revealed that the lowest organic carbon content 0.55 per cent was recorded in control treatment where no fertilizer was practiced. However, the organic carbon values improved significantly with combined application of chemical fertilizers along with the organic manure. Similar findings were reported by ${ }^{[9]}$ reported that continuous application of chemical fertilizer in soil, reduced the quantity of organic carbon content in soil, while continuous application of chemical fertilizer along with FYM organic manure increased the organic carbon content in soil because addition of large amount of crop residues in soil and increased the microbial population in soil which increased the decomposition of crop residues which increased the organic carbon content was obtained at the surface soil.

\section{Available Nitrogen}

The data pertaining to the impact of organic and inorganic fertilizer nutrients on available nitrogen content in surface soil are given in Table 1. Data clearly indicated that available nitrogen content in soil was significantly affected by different treatments. Data further revealed that available nitrogen content was maximum found in NPK $100 \% \mathrm{RDF}+5$ ton FYM ha ${ }^{-1}$ treatment while it was lowest under control treatment. Higher value of available nitrogen content in surface soil after harvest of soybean crop was recorded in the treatments of balanced application of nutrients and lower in no fertilizer application treatments similar findings were reported by ${ }^{[6]}$ observed that combined use of inorganic fertilizers and organic manure (FYM) increased the available nitrogen in surface soil.

\section{Available Phosphorus}

Application of organic along with inorganic fertilizers recorded significantly increased the available phosphorus content in soil than all other treatments during soybean crop (Table 1). The highest available phosphorus content in surface soil was recorded in the NPK $100 \% \mathrm{RDF}+5$ ton FYM ha${ }^{1}$ followed by NPK $100 \%$ alone. The lowest available phosphorus content was found in control treatment. Among organic fertilizers applied in Kharif season in soybean crop, highest available phosphorus content was recorded by NPK $100 \% \mathrm{RDF}+5$ ton FYM ha-1. It might be due to the decomposition of the farm yard manure converted into humus and releases the different types of organic acids in soil which helps to release the native phosphorus or bound phosphorus from the $\mathrm{Fe}$ and $\mathrm{Al}$ minerals, so available phosphorus content is increased in soil which is easily taken up by the plants similar findings were reported by ${ }^{[4]}$.

\section{Available Potassium}

Data clearly indicated that available potassium content in surface soil was significantly affected by different treatments of nutrient application. Data further revealed that highest available potassium content was recorded in the treatment NPK $100 \%$ RDF +5 ton FYM ha ${ }^{-1}$ and lowest was recorded in the un-manured control treatment. The results clearly indicated that integration of organic source with inorganic nutrients increased the available potassium content in surface soil with the respective of the nutrients application treatments. 
It might be because of addition of FYM or organic residue and inorganic fertilizer in surface soil increased the available potassium content in the surface soil after harvest of soybean crop. Similar findings were reported by ${ }^{[5]}$ also reported that application of organic manures or organic residues in soil increased the available potassium in soil.

\section{Conclusions}

Our results showed that chemical properties (O.C. available $\mathrm{N}, \mathrm{P}, \mathrm{K})$ of the surface soil after harvest of soybean crop were significantly altered by combined application of integrated nutrients. However, treatments of application of integrated nutrients did not affected $\mathrm{pH}$, EC of the surface soil significantly neither after harvest of soybean crop.

Table 1: Impact of organic and inorganic nutrient resources on soil properties after harvest of Soybean crop during year 2014-15.

\begin{tabular}{|c|c|c|c|c|c|c|}
\hline Treatment & $\begin{array}{c}\text { pH } \\
(1: 2)\end{array}$ & $\left|\begin{array}{c}\mathbf{E C} \\
\left(\mathbf{d S m}^{-1}\right)\end{array}\right|$ & $\begin{array}{l}\text { O.C. } \\
(\%)\end{array}$ & $\begin{array}{c}\text { Available N } \\
\left(\mathrm{Kg} \mathrm{ha}^{-1}\right)\end{array}$ & $\begin{array}{c}\text { Available } \\
\mathrm{P}_{2} \mathrm{O}_{5} \\
\left(\mathrm{Kg} \mathrm{ha}^{-1}\right) \\
\end{array}$ & \begin{tabular}{|c} 
Available \\
$\mathrm{K}_{2} \mathrm{O}$ \\
$\left(\mathrm{Kg} \mathrm{ha}^{-1}\right)$ \\
\end{tabular} \\
\hline Control & 6.79 & 0.12 & 0.55 & 151.50 & 10.33 & 125.13 \\
\hline NPK $100 \%$ RDF & 7.04 & 0.17 & 0.71 & 174.50 & 13.75 & 143.65 \\
\hline NPK 50\% RDF & 6.99 & 0.16 & 0.64 & 161.38 & 12.33 & 138.23 \\
\hline NPK 100\% RDF + 5 kg ZnSO4 ha ${ }^{-1}$ & 7.07 & 0.18 & 0.74 & 181.50 & 14.00 & 146.81 \\
\hline STCR Targeted yield 1 (inorganic mode) & 6.93 & 0.16 & 0.69 & 189.78 & 15.17 & 149.07 \\
\hline STCR Targeted yield 2 (inorganic mode) & 7.00 & 0.18 & 0.73 & 196.27 & 16.55 & 157.20 \\
\hline NPK 100\% RDF + 5 ton FYM ha ${ }^{-1}$ & 7.20 & 0.21 & 0.90 & 214.47 & 20.15 & 162.17 \\
\hline NPK 50\% RDF + 5 ton FYM ha ${ }^{-1}$ & 7.07 & 0.19 & 0.81 & 199.33 & 18.08 & 159.91 \\
\hline STCR Targeted yield 1 (organic mode +5 ton FYM ha $\left.{ }^{-1}\right)$ & 7.14 & 0.18 & 0.76 & 206.50 & 17.08 & 150.43 \\
\hline STCR Targeted yield 2 (organic mode +5 ton FYM ha ${ }^{-1}$ ) & 7.15 & 0.19 & 0.79 & 210.47 & 19.08 & 159.01 \\
\hline $\mathrm{S} . \mathrm{Em} \pm$ & 0.14 & 0.03 & 0.01 & 0.44 & 0.34 & 0.66 \\
\hline C.D. at $5 \%$ & NS & NS & 0.03 & 1.33 & 1.01 & 0.76 \\
\hline
\end{tabular}

\section{References}

1. Bhatt B. Effect of long term fertilizer application in ricewheat system on crop productivity and soil. Ph. D. Thesis submitted to G.B.P.U.A. \& T. Pantnagar, India. 2012, 135.

2. Chesti MH, Kohli A, Sharma AK. Effect of integrated nutrient management on yield and nutrient uptake by wheat (Triticum aestivum) and soil properties under Intermediate zone of Jammu and Kashmir. Journal of the Indian Society of Soil Science. 2013; 6(1):1-6.

3. Eid RA, Sedera A, Attia M. Influence of nitrogen fixing bacteria incorporation with organic and inorganic fertilizers on growth, flower yield and chemical composition of celosia argentia. World Journal of Agricultural Sciences. 2006; 2(4):450-458.

4. Krishna D, Ram S, Ram N. Response of long term use of NPK fertilizers and manure fractions, soil properties and their relationship to yields of rice in rice-wheat -cowpea cropping system on a Mollisol of Tarai. Pantnagar Journal of Research. 2007; 5(2):108-113.

5. Sharma MP, Gupta JP. Effect of organic materials on grain yield and soil properties in maize-wheat cropping system. Indian Journal of Agricultural Sciences. 1998; 68:715-717.

6. Sharma SK, Sharma SN. Integrated nutrient management for sustainability of rice-wheat cropping system. Indian Journal of Agricultural Sciences. 2002; 72(10):573-129.

7. Sime T. Long term effect of fertilizers and manures on the availability and uptake of calcium, magnesium and sulphur by wheat in a Mollisol. Thesis, Master of Science in Agriculture (Soil Science), G.B.P.U.A. \& $\mathrm{T}$. Pantnagar. 2001, 5-19.

8. Tyagi VV. Soil fertility status and physic chemical status of an Aquic Hapludoll as influenced by 16 years of continuous cropping and fertilization. Thesis M.Sc. (Ag.) submitted to G.B.P.U.A. and T., Pantnagar. (U.S. Nagar). 1989, 10-24.

9. Yadhuvanshi NPS. Ammonia volatilization losses from integrated nutrient management. Journal of Indian Society of Soil Science. 2001; 45(2):276-280. 